\title{
Future earnings growth volatility and the value premium
}

\author{
Jamie Alcock ${ }^{1, A}$, Eva Steiner ${ }^{\mathrm{B}}$ and Kelvin Jui Keng Tan ${ }^{\mathrm{C}}$ \\ A The University of Cambridge, United Kingdom, and The University of \\ Queensland, Australia \\ в The University of Cambridge, United Kingdom \\ ${ }^{\mathrm{C}}$ The University of Queensland, Australia
}

\begin{abstract}
The value premium is well established in empirical asset pricing, but to date there is little understanding as to its fundamental drivers. We use a stochastic earnings valuation model to establish a direct link between the volatility of future earnings growth and firm value. We illustrate that risky earnings growth affects growth and value firms differently. We provide empirical evidence that the volatility of future earnings growth is a significant determinant of the value premium. Using data on individual firms and characteristic-sorted test portfolios, we also find that earnings growth volatility is significant in explaining the cross-sectional variation of stock returns. Our findings imply that the value premium is the rational consequence of accounting for risky earnings growth in the firm valuation process.
\end{abstract}

Key words: Asset pricing, Fama-French factor model;

JEL Classification: G12, G14

1 Corresponding Author: Department of Land Economy, The University of Cambridge, United Kingdom. Telephone +44 (0) 1223337 152, Fax +44 (0) 1223337 130, Email jta27@cam.ac.uk. We thank Kevin Aretz for making available his data set on aggregate firm survival probability recreated from Vassalou and Xing (2004), and Stephen Penman for helpful comments and suggestions. We also thank the participants of the 2011 EFMA Conference in Braga and the 2011 Asian FA Conference in Macao for their constructive comments and suggestions. 


\section{Introduction}

Fama and French's (1992) value premium is well established in the empirical asset pricing literature. However, the fundamentals that drive this result remain unclear. One stream of research seeks to provide rational, risk-based explanations for the value premium. Within this body of literature, several studies establish an empirical link between the value premium and a set of macroeconomic variables that are thought to proxy for shifts in the investment opportunity set (Aretz, Bartram, and Pope, 2010; Vassalou, 2003). Others suggest that the value premium reflects compensation for systematic risks beyond the market factor (Fama and French, 1996; Garcia-Feijoo and Jorgensen, 2010). In the absence of a fully satisfactory rational explanation, an alternative stream of research suggests that the value premium reflects mispricing based on cognitive biases (Daniel and Titman, 1997; Lakonishok, Shleifer, and Vishny, 1994).

We argue that the value premium is, at least partially, based on the uncertainty of future earnings growth and its effect on firm value. The difference between current book and market value of equity reflects investor expectations of future earnings growth. For growth firms, traditional DCF valuation models factor a positive constant rate of expected earnings growth into the rate used to discount future earnings, thereby increasing the present value of future earnings and the market value of equity relative to its book value. In this framework, future earnings growth is assumed to be deterministic. However, many fundamental economic reasons exist for unforeseen shocks to the growth rate, ranging from business cycle fluctuations to uncertainty of management outcomes. As a result, earnings growth may be subject to random fluctuations through time and thus, at least in part, stochastic.

We consider risky earnings and their effect on firm valuation in the context of a stochastic earnings valuation model (Alcock, Mollee, and Wood, 2011). We show that in this contingent claim framework, firm value rises with increasing earnings growth volatility. However, given the non-linearity in the value function, this increase is not uniform over all firms, and it is the differential influence of earnings growth volatility on growth and value firms that drives the value premium.

The information content of risky future earnings has recently been explored in the literature. For instance, Dichev and Tang (2009) examine the ability of analysts to forecast firm earnings in the presence of earnings volatility, and find that conditioning 
on earnings volatility enables the identification of large and predictable forecast errors. At the same time, the current understanding of the possible link between uncertain future earnings and firm value or investment returns is incomplete.

Penman and Reggiani (2011) argue that the value premium is a consequence of current accounting practice for accommodating earnings risk. Risky earnings are deferred until the uncertainty is resolved and earnings are realised. Earnings deferral reduces the ratio of earnings to price in the short term and compresses the value of earnings relative to book value. Lower earnings in relation to the book value detract from price, thereby increasing the book to market ratio. Therefore, Penman and Reggiani (2011) and Penman, Reggiani, Richardson, and Tuna (2011) conclude that a high book to market ratio implies high earnings risk, and that a value firm carries more risk than a growth firm. The positive differential return between these types of stocks, the value premium, then reflects the compensation for earnings risk. This accounting-based perspective on the source of the value premium implies a paradigm shift in the interpretation of the relative risks embedded in growth and value firms. The key insight we propose in the context of the stochastic earnings valuation model is that the value-enhancing effect of identical levels of earnings risk differs between growth and value firms.

We provide empirical evidence that earnings growth volatility is significantly related to the value premium after controlling for a comprehensive set of macroeconomic factors commonly found to proxy for changes in the investment opportunity set. Further, we find that earnings growth volatility is significant in the explanation of the cross-section of stock returns. The significance of earnings growth volatility is not subsumed by firm characteristics often found to represent sources of risk beyond the market factor. We also find that earnings growth volatility is a significant factor in pricing a traditional set of test assets (Fama and French, 1992, 1993) as well as an expanded set of test assets recently proposed by Daniel and Titman (2011) that increases the power of factor model tests.

We proceed by reviewing related literature in Section 2. We illustrate the relationship between earnings growth volatility and firm value in Section 3. We present our methodology and the empirical results in Sections 4 and 5. Section 6 concludes. 


\section{Related literature}

Fama and French (1992) empirically identify two stock characteristics, size (market equity) and the ratio of book- to market-equity, that appear to capture a significant proportion of the cross-sectional variation in stock returns. Fama and French (1993) and Loughran (1997) show that these common characteristic return factors (henceforth SMB for size and HML for book-to-market, together the FF factors) significantly increase the proportion of variation in the cross-section of stock returns that is explained by the market factor alone. Fama and French (1996) argue that many of the firm characteristics typically found to cause anomalies in asset pricing, i.e. inconsistencies with the traditional CAPM, such as the reversal of long-term returns, size, book-to-market, earnings relative to price, cash flow relative to price or past sales growth (Banz, 1981; Basu, 1983; DeBondt and Thaler, 1985; Fama and French, 1995; Rosenberg, Reid, and Lanstein, 1985), are related and in fact absorbed by SMB and HML from the Fama and French (1993) three-factor model. Fama and French (1998) and Chui and Wei (1998) present evidence for the pervasiveness of the FF factors in international stock returns.

Factors in rational asset pricing models proxy for risk factors in returns (Lewellen, 1999). Without an underlying economic rationale, the FF factors remain arbitrary indicators void of an interpretation as systematic risk factors that are priced separately from the market factor. Merton's intertemporal CAPM suggests that investors are compensated for market risk, but also for the risk of adverse shifts in the investment opportunity set. Cochrane (2005) argues that macroeconomic measures represent likely sources of priced risk factors as they reflect dynamics in the business climate and changes in non-financial market income. This insight provides the foundation for a stream of research into a suitable set of macroeconomic state variables that proxy for shifts in investment opportunities. ${ }^{2}$

We can observe two approaches in this body of literature: i) direct tests for the predictive power of the $\mathrm{FF}$ factors for changes in the investment opportunity set, often proxied by aspects of changes in future economic growth, and ii) tests for the pervasiveness of the predictive power of the $\mathrm{FF}$ factors for cross-sectional variation of stock returns in the presence of factors that are thought to proxy for changes in the investment opportunity set.

2 Alternative explanations of the empirical success of the FF factors include cognitive biases (Daniel and Titman, 1997), data selection biases (Kothari, Shanken, and Sloan, 1995; Lo and MacKinlay, 1990), delisting biases (Shumway and Warther, 1999), or data snooping (Black, 1993). 
In line with the first approach, Liew and Vassalou (2000) establish a relationship between SMB/HML and future economic growth. The explanatory power of the FF factors for future GDP growth persists when controlling for the market factor and a set of commonly employed business cycle variables. Kelly (2004) expands this analysis by considering innovations in real GDP growth and unexpected inflation and finds that the value premium is positively correlated with real GDP growth. SMB is negatively correlated with inflation, and positively with real economic growth.

In line with the second approach, Vassalou (2003) constructs a mimicking portfolio for news related to future nominal GDP growth and shows that this factor largely supersedes HML and SMB in explaining the cross-sectional variation in average asset returns. Hahn and Lee (2006) employ a similar approach and suggest that macro-economic variables closely linked to fluctuations of the business cycle, the default spread and the term spread, contain much of the information captured by SMB and HML. Petkova (2006) focuses on two different aspects of the investment opportunity set, namely the yield curve and the conditional distribution of asset returns, and considers a set of indicators including the short-term interest rate, the aggregate dividend yield and the default spread. The chosen set of innovation factors appears to supersede the FF factors in the explanation of the cross-section of returns. Ghargori, Chan, and Faff (2007) find no relationship between SMB and default risk. Aretz, Bartram, and Pope (2010) unify prior efforts by considering a more comprehensive set of shocks to macroeconomic fundamentals and find that the FF factors embody much of the information contained in those fundamentals.

What most of the research into the economic meaning of the FF factors has in common is a purely empirical perspective, often relying on previously established links between fundamentals and stock returns. Most studies to date stop short of developing a theoretical relationship between the FF factors and the variables that act as a proxy for the hypothesised underlying economic risk factors. We propose an explicit relationship between the value premium and earnings growth volatility.

Lakonishok, Shleifer, and Vishny (1994) and, similarly, Hall and Tochterman (2008) find that the value premium is related to investor's incorrect extrapolation of high levels of historical earnings growth into the future. These results suggest that the market is inefficient in pricing future growth volatility. We argue that the value premium is in fact consistent with rational pricing once the relative effects of the stochastic nature of earnings growth on value and growth stocks are accounted for. 


\section{Earnings growth volatility and the value premium}

We examine the influence of volatile earnings growth on firm value in a stochastic earnings valuation model, SEVM (Alcock, Mollee, and Wood, 2011). The basic building block of the SEVM is a differential equation for earnings expressed as a function of a drift component that represents expected growth, and a variance component that reflects the stochastic element of total earnings growth. Traditional models of firm valuation capture the drift component of earnings growth and quantify its impact on the market value of equity, but ignore the variance component. The SEVM identifies the uncertainty surrounding future earnings growth as a source of value that contributes to the market value of equity.

Earnings $E_{t}$ that grow over time at a constant rate $\bar{g}$ can be modelled using the ordinary differential equation $d E_{t}=\bar{g} E_{t} d t$. If we consider earnings growth to be partly stochastic, then the growth rate has a non-zero drift and variance component such that $\overline{g_{t}}=g+\sigma \Psi_{t}$, where $\Psi_{t}$ is a white noise process. In this case, the differential equation for earnings is given by:

$$
d E_{t}=g E_{t} d t+\sigma E_{t} d W_{t}
$$

where $W_{t}$ is a standard Wiener process ${ }^{3}$. In the SEVM, we assume that the earnings of a firm with finite life $T$ are continuously deposited into a bank account whose current value, $A_{t}$, is given by:

$$
A_{t}=\int_{0}^{t} e^{r_{f}(t-s)} E_{s} d s
$$

Equity is modelled as a call option on the balance of this bank account. The variation in equity, $d P$, is then given by:

$$
d P=\frac{\partial P}{\partial A} d A+\frac{\partial P}{\partial E} d E+\frac{\partial P}{\partial t} d t+\frac{1}{2} \frac{\partial^{2} P}{\partial E^{2}}(d E)^{2}
$$

where $d A=\left(E+r_{f} A\right) d t$ and $(d E)^{2}=\sigma^{2} d t$.

The earnings of most firms cannot be guaranteed to be a strictly positive process. Valuing firms with periods of negative earnings in any of the current valuation frameworks requires some restrictive assumptions be placed on the earnings process. For example, the DCF can value firms with negative earnings if the timing and value of any negative earnings are anticipated. For the model described above, if the true earnings process, $E_{t}$, is bounded below by $-\kappa$ then we can define $\tilde{E}_{t}=E_{t}+\kappa$ to be a strictly positive earnings process governed by a GBM (1). This is less stringent than requiring that the timing and value of any negative earnings are anticipated. Rather we only require that the minimum of any negative earnings is anticipated. 
Standard equilibrium arguments give the value of equity in terms of the partial differential equation (PDE):

$$
\frac{\partial P}{\partial t}+\left(E+r_{f} A\right) \frac{\partial P}{\partial A}+g E \frac{\partial P}{\partial E}+\frac{1}{2} \sigma^{2} E^{2} \frac{\partial^{2} P}{\partial E^{2}}-\left(r_{f}+\lambda\right) P=0
$$

where $\lambda$ represents the market price of earnings risk, the value of which will depend upon the risk preferences of the marginal investor. This parameter is non-zero as it is not yet possible to fully hedge earnings risk.

We set the auxiliary variable $R_{t}=\frac{A_{t}}{E_{t}}$. $H$ represents a call option on $R_{t}$. The value of $H$ is given by the price of earnings (the price-earnings or PE ratio) that follows the following PDE:

$$
\frac{\partial H}{\partial t}+\left(1+\left(r_{f}-g\right) R_{t}\right) \frac{\partial H}{\partial R_{t}}+\frac{1}{2} \sigma^{2} R_{t}^{2} \frac{\partial^{2} H}{\partial R_{t}{ }^{2}}+\left(g-r_{f}-\lambda\right) H=0,
$$

The PDE for the price of earnings has the following boundary conditions:

$$
\begin{aligned}
\lim _{R_{t} \rightarrow \infty} \frac{\partial^{2} H}{\partial R_{t}{ }^{2}} & =0, \quad \text { as } \quad R_{t} \rightarrow \infty \\
\frac{\partial H}{\partial t}+\frac{\partial H}{\partial R_{t}}+\left(g-r_{f}-\lambda\right) H & =0, \quad \text { along } \quad R_{t}=0
\end{aligned}
$$

In the absence of debt, the equity value at maturity is given by:

$$
P_{T}=\max \left(A_{T}, 0\right) \Longrightarrow H_{T}=\max \left(R_{T}, 0\right)=R_{T}
$$

Earnings growth volatility affects the PE ratio, determined in (4) to (7), of growth and value stocks differently. In absolute terms, earnings growth volatility adds greater value to the equity of the growth firm than to that of the value firm. If investor returns are measured in absolute terms, volatility is preferred in a growth firm as opposed to a value firm (Figures 1(a) and (b)).

However, investors typically measure investment returns relative to the amount invested. The relative effect of earnings volatility for both the growth and value firm can be examined by scaling the $\mathrm{PE}$ ratios by the $\mathrm{PE}$ ratio for the $\sigma=0$ case. The $\mathrm{PE}$ ratio calculated for $\sigma=0$ is consistent with the $\mathrm{PE}$ ratio obtained using the DCF $\mathrm{PE}$ ratio. The scaled $\mathrm{PE}$ ratios are presented in Figures 2(a) and (b). In relative terms, earnings volatility adds value to both, the growth firm and the value firm. However, given equal leverage, the relative increase in equity value is greater for the value stock. 
The difference between the influence of earnings growth volatility on the returns of growth and value firms lies in the nonlinear nature of the contingent claim valuation. If equity value is modelled as a contingent claim on future earnings of the firm, then the volatility of future earnings is a major driver of value, and hence also of returns. Earnings growth volatility will have an equal impact on the value of low and high book to market firms only if the earnings drift is equal for both firm types. As earnings risk is not hedgeable, the expected growth of earnings will affect the firm valuation differently for growth and value firms.

Accordingly, earnings growth volatility will affect equity returns differently across growth and value firms. Indirectly, earnings growth volatility affects the returns on growth and value firm differently because earnings risk is not tradeable. In a traditional DCF framework, earnings volatility represents a genuine surprise that is not accounted for. This insight implies that in a traditional valuation model, the value of a high book to market firm is relatively more underestimated than that of a low book to market or growth firm, explaining the relative outperformance of value firms. An increase in earnings growth volatility enhances the value of a high book to market firm relatively more, compressing expected returns more severely in

relative terms, thus decreasing the value premium. Two main testable hypotheses follow from this discussion:

H1: There is an inverse relationship between earnings growth volatility and the value premium.

H2: To the extent that earnings growth volatility is reflected in the value premium, it is significantly related to the cross section of stock returns.

\section{Data and methodology}

\subsection{Firm data}

We test each of our hypotheses on all NYSE, Amex and Nasdaq non-financial firms in the cross-section of the CRSP monthly stock return and Compustat annual industrial files from 1962-2010. Following Fama and French (1992) we form all accounting variables at the end of June of year $t$, using data from the fiscal year-end $t-1$. At the end of June in year $t$, stocks are allocated into equally-weighted decile portfolios that are determined by earnings growth volatility cut-off points. 
Earnings growth volatility is defined as the standard deviation of earnings (McInnis, 2010) that are measured between the end of year $t$ and $t+3$. The portfolios are held from July $t$ to June $t+1$, and then rebalanced.

On the basis that earnings growth volatility produces significant variation in stock returns, we form an earnings growth volatility characteristic factor. The earnings growth volatility factor is obtained in two steps. First, we sort sample stocks according to earnings growth volatility. Then we calculate the equally-weighted average excess return of the resulting decile portfolios over the one-month T-bill. We take the difference between the top and bottom $30 \%$ of decile portfolio excess returns to mimic a portfolio that is long in high earnings growth volatility stocks and short in low earnings growth volatility stocks. This procedure allows us to relate earnings growth volatility directly to the value premium and other factors commonly represented in empirical asset pricing.

\subsection{Methodology}

Hypothesis 1: The inverse relationship between HML and EGVOL In order to test our first hypothesis, we run the following regression:

$$
\begin{aligned}
H M L_{t} & =\alpha+\beta_{1} E G V O L_{t}+\beta_{2} M Y P_{t}+\beta_{3} U I_{t}+\beta_{4} D S V_{t} \\
& +\beta_{5} A T S_{t}+\beta_{6} S T S_{t}+\beta_{7} F X_{t}+\epsilon_{t}
\end{aligned}
$$

where $H M L_{t}$ is the value premium in month $t, \alpha$ is a constant, and $E G V O L_{t}$, the variable of interest, is the earnings growth volatility factor in month $t$. As we predict an inverse relationship between earnings growth volatility and the value premium, we expect a negative sign on the coefficient $\beta_{1} . \epsilon_{t}$ is an iid residual with zero mean. The monthly data to estimate (8) covers the period 1987 (the first date for which the Treasury data required to form STS and ATS is available) to 2010.

Our choice of control variables in (8) follows Aretz, Bartram, and Pope (2010) who present a comprehensive multi-factor model that unifies prior research into individual macroeconomic factors that may influence the value premium. Unless otherwise indicated, all macroeconomic and financial data in this analysis is from Datastream. We control for unexpected changes in the CPI in month $t$, denoted $U I_{t-1, t}$, that we obtain as the residuals from estimating actual inflation as an MA(1) process (Fama and Gibbons, 1984). $D S V_{t}$ are monthly changes in the aggregate firm survival probability, obtained from Aretz, Bartram, and Pope (2010). 
Aretz, Bartram, and Pope (2010) recreate the original series from Vassalou and Xing (2004) over an extended time period. $A T S_{t}$ and $S T S_{t}$ are the monthly average level and the slope of the term structure proxied by the yields on 10-year and 3-month US Treasuries from the Federal Reserve. $F X_{t}$ are monthly changes in the exchange rate between the US\$ and a broad trade-weighted basket of major currencies.

The control variable $M Y P$ represents news to one-year ahead expectations of industrial output growth and should capture innovations in cash flow expectations. Given the strong conceptual link to our variable of interest, this control is crucial to distinguishing the effect on HML we hypothesise from general fluctuations in output growth expectations. Since the $M Y P$ factor is unobservable, we follow the approach proposed in Lamont (2001), and create a factor-mimicking portfolio from a broad set of base assets in two steps. First, we estimate:

$$
\begin{aligned}
\Delta L N O U T_{t, t+12} & =\beta_{1} M K T_{t-1, t}+\beta_{2} L T G_{t-1, t}+\beta_{3} M T G_{t-1,1}+\beta_{4} H Y G_{t-1, t} \\
& +\beta_{5} G L D_{t-1, t}+\beta_{6} S L O P E_{1987}+\beta_{7} S L O P E_{1996-2002}+\epsilon_{t}
\end{aligned}
$$

where $\triangle L N O U T$ is the log-change in actual industrial output growth from today, $t=0$, to twelve months from today, $t=12$. The base assets are the excess return over the 1-month T-Bill from $t-1$ to $t$ on the market, denoted $M K T_{t-1, t}$, on long- and medium-term government bonds, $L T G_{t-1, t}$ and $M T G_{t-1, t}$, on a highyield bond portfolio, $H Y G_{t-1, t}$, and on gold, $G L D_{t-1, t}$. We also include a slope dummy on the market portfolio excess return in 1987, SLOP $E_{1987}$, and in 19962002, SLOP $E_{1996-2002}$, to allow for time variation in the resulting portfolio weight for the market during the 1987 crash and the 1996-2002 internet bubble (Aretz, Bartram, and Pope, 2010).

Given the restricted availability of the Treasury data, the study period for the estimation of MYP is 1987 to 2010. Standard errors in (9) are corrected for heteroskedasticity and autocorrelation using the Newey and West (1987) adjustment with lags $l=11$ to reflect the annual horizon of the analysis that is based on monthly data. The results of this regression are shown in Appendix A. Following Lamont (2001), we obtain the coefficients on the base assets from (9) and use them to estimate the values of expected changes in industrial output growth over the next year. This second step results in the variable $M Y P$. We correct standard errors in (8) for the generated regressor using the Murphy and Topel (1985) procedure. 


\section{Hypothesis 2: EGVOL and the cross-section of stock returns}

We test this hypothesis in a number of different ways that we consider in turn. We propose that the value premium at least partially reflects earnings growth volatility. Since the value premium is significant in explaining the cross section of stock returns, we expect earnings growth volatility to be significant too, separately from other systematic risk factors. In order to examine this conjecture, we follow Cooper, Gulen, and Schill (2008) and estimate the following Fama MacBeth regressions:

$$
\begin{aligned}
R_{i t} & =\alpha_{i}+\beta_{1} E G V O L_{i t}+\beta_{2} M K T_{i t}+\beta_{3} A C C_{i t}+\beta_{4} C A P_{i t}+\beta_{5} N O A_{i t} \\
& +\beta_{6} E P_{i t}+\beta_{7} L E V_{i t}+\beta_{8} I S S_{i t}+\beta_{9} L A G_{i t}+\beta_{10} L 2 A G_{i t}+\beta_{11} B M_{i t} \\
& +\beta_{12} M V_{i t}+\beta_{13} B H 6_{i t}+\beta_{14} B H 36_{i t}+\epsilon_{i t}
\end{aligned}
$$

where $R_{i t}$ is the return on firm $i$ in year $t, \alpha$ is a constant, and $E G V O L_{i t}$ is the earnings growth volatility of firm $i$ measured as the standard deviation of earnings between the end of year $t$ and $t+3$. We expect a negative sign on the corresponding coefficient $\beta_{1}$. This step employs annual data from 1962-2010. The use of geometrically compounded annual firm returns mitigates market microstructure issues arising from the use of monthly CRSP closing prices (Cooper, Gulen, and Schill, 2008).

McInnis (2010) uses the standard deviation of realised earnings as a proxy for earnings growth volatility. Our focus is on future earnings growth volatility. We proxy for future earnings growth volatility using the standard deviation of actual future earnings. Only the expectation of future earnings over $t+n$ can be priced at time $t$. The quality of our proxy therefore depends on the correlation between expectations of future earnings conditional upon past earnings information, and actual future earnings. In support of this argument, Dichev and Tang $(2009,2008)$ document the predictive power of past earnings volatility for the persistence of current earnings.

Given the vast literature on firm characteristics determining the cross-section of stock returns, we include the following controls, largely following Cooper, Gulen, and Schill (2008): $M K T_{i t}$ is the firm's familiar CAPM beta (Fama and French, 1992, 1993). $A C C_{i t}$ measures accruals (Sloan, 1996). $C A P_{i t}$ is capital expenditure and investment (Titman, Wei, and Xie, 2004). NOA $i t$ is the ratio of net operating assets over total assets (Hirshleifer, Hou, Teoh, and Zhang, 2004). EP $i$ it is the earnings to price ratio (Basu, 1983). $L E V_{i t}$ is leverage from Bhandari (1988). IS $S_{i t}$ represents issuance as in Pontiff and Woodgate (2008). 
Further, $L A G_{i t}$ and $L 2 A G_{i t}$ are one- and two-years lagged values of asset growth (Cooper, Gulen, and Schill, 2008). $M V_{i t}$ is the size effect from Banz (1981); Keim (1983). $B M_{i t}$ is the book to market effect documented in Rosenberg, Reid, and Lanstein (1985) and Stattman (1980). BH6 $6_{i t}$ and BH36 it are 6- and 36-month (leading up to month $t$ ) buy and hold returns on firm $i$ as proposed in DeBondt and Thaler (1985) and Jegadeesh and Titman (1993). The variables in our empirical analysis are defined as proposed by the original authors.

Having established the relationship between HML and EGVOL as well as between the cross-section of stock returns and EGVOL, we combine the two perspectives and examine the role of the EGVOL factor in pricing the Fama French 25 portfolios sorted by size and book to market ratio. We run the following Fama MacBeth regressions:

$$
R_{i j, t}=\alpha+\beta_{1} M K T_{t}+\beta_{2} S M B_{t}+\beta_{3} H M L_{t}+\beta_{4} E G V O L_{t}+\beta_{5} M O M_{t}+\epsilon_{t}
$$

where $R_{i j, t}$ is the excess return over the 1-month T-Bill in month $t$ on portfolio $i j$ where $i=1,2, \ldots, 5$ indicates the size (market value) bracket and $j=1,2, \ldots, 5$ indicates the value (BM) bracket of the portfolio. $\alpha$ is a constant term. $M K T_{t}$ is the market factor, $S M B_{t}$ is the size effect, and $H M L_{t}$ is the value premium. We augment this model by the momentum factor $M O M_{t}$ proposed in Carhart (1997). Data on the market, size, value and momentum factors as well as the risk-free rate are from Kenneth French's website. This step employs monthly data from 1962-2010.

$E G V O L_{t}$ is our candidate earnings growth volatility factor. The EGVOL factor represents the monthly excess return on a portfolio long in high volatility stocks and short in low volatility stocks. Since volatility adds value in the stochastic earnings valuation framework, we expect the excess return on the EGVOL factor to be, on average, negative. We expect the EGVOL factor overall to detract from the crosssection of stock returns and thus a negative sign on $\beta_{4}$.

Following Hahn and Lee (2006) and in order to facilitate comparisons with the full model in (11), we estimate a CAPM specification suppressing everything but MKT, a Fama and French 3-factor specification with MKT, HML and SMB, a corresponding version with HML replaced by EGVOL, as well as a 4-factor model augmented by MOM. In our comparisons, we largely focus on the explanatory power, measured by the average adjusted $R^{2}$, the consistence of the significance and magnitude of the coefficient estimates and the pricing error measured by the constant term. 
Daniel and Titman (2011) question the statistical power of asset pricing tests based on the traditional characteristic-sorted portfolios. We repeat the estimation of (11) using an expanded set of test assets including 100 (10x10) portfolios sorted according to book to market ratio and systematic risk measured by 5 -year rolling CAPM $\beta$ 's. Daniel and Titman (2011) examine three factor models proposed in the literature and find that the new test assets seem more difficult to price as they reject several of the proposed models. Evidence consistent with our hypotheses that is determined using the 10x10 portfolios will significantly support the robustness of our findings.

Hypothesis $H 2$ also implies that EGVOL affects value and growth portfolios differently. In order to test this implication, we repeat the Fama and French 25 portfolio pricing exercise, but in the second stage of the Fama MacBeth regressions we add an interaction term $V A L \times E G V O L$ that captures the differential effect of earnings growth volatility on value portfolios defined as those portfolios that are not in the lowest book to market bracket for each size bracket. We reestimate (11) as follows:

$$
\begin{aligned}
R_{i j, t} & =\alpha+\beta_{1} M K T_{t}+\beta_{2} S M B_{t}+\beta_{3} H M L_{t} \\
& +\beta_{4} E G V O L_{t}+\beta_{5} M O M_{t}+\beta_{6} V A L+\beta_{7} V A L \times E G V O L_{t}+\epsilon_{t}
\end{aligned}
$$

While the coefficient on the dummy $V A L$ itself is difficult to interpret in a Fama MacBeth regression, our hypothesis suggests that the overall effect of earnings growth volatility on value portfolios is negative, in other words we anticipate $\left(\beta_{4}+\beta_{7}\right)<0$.

\subsection{Descriptive statistics}

Table 1 reports the financial and return characteristics of the first (lowest earnings growth volatility) and tenth (highest earnings growth volatility) decile portfolio alongside the spread between them. The time series average of the yearly crosssectional medians of earnings growth volatility for the tenth portfolio is substantially larger than for the first portfolio. Low earnings growth volatility firms experience stronger asset growth than their high volatility counterparts, and they are larger in terms of assets and market values. Low earnings growth volatility firms display relatively lower book-to-market ratios and relatively higher earnings-to-price ratios alongside higher leverage. The return on assets generated by low earnings growth volatility firms is higher than for high volatility firms, so are their six- and 36-month buy-and-hold returns (momentum). Accruals as well as issuance are higher for low earnings growth volatility firms than for their high volatility counterparts. 
Table 2 provides information about the persistence of differences in earnings growth volatility between the decile portfolios relative to their formation at the end of June of year $t$. The spread between the first (lowest) and tenth (highest) earnings growth volatility portfolios is highly significant not only in the formation year, but remains significant five years prior to and five years following formation. The observation of persistence in earnings is consistent with Frankel and Litov (2009).

Table 3 illustrates that our decile portfolios not only differ persistently in their earnings growth volatility characteristics but also produce significantly different returns at the time of formation and in the years around their formation. This observation provides preliminary support for our approach of forming an earnings growth volatility factor to examine its influence on the cross section of stock returns.

Table 4 provides details on the earnings growth volatility factor as well as the Fama and French and momentum factors. The mean value of the earnings growth volatility factor is negative, which is consistent with our expectations. The value is close to zero and thus might be easily overlooked at first, but its standard deviation is one of the highest among the factors under consideration. Also, the earnings growth volatility factor has the highest value of autocorrelation among all factors considered here, implying a relatively higher degree of persistence.

The lower part of Table 4 shows the Pearson pairwise correlation coefficients between the factors. As we conjecture in our theoretical proposition, there is a significant negative correlation between the value premium and the earnings growth volatility factor. There is also a significant positive correlation between the size factor and the earnings growth volatility factor. It is conceivable that smaller firms are the ones that exhibit higher earnings growth volatility, a characteristic potentially related to younger firm age and maturity. We control for the size effect in our empirical analysis in order to ensure our findings are not in fact a result of this effect.

\section{Results}

\subsection{Hypothesis 1: The inverse relationship between HML and EGVOL}

We first explore the influence of earnings growth volatility on the value premium HML using the earnings growth volatility factor EGVOL that we have created. Table 5 shows that, consistent with our hypothesis, earnings growth volatility appears to have a significant inverse relationship with the value premium. 
If earnings growth volatility increases, holding all else equal, the price of value stocks rises more than the price of growth stocks, thereby decreasing expected returns for value stocks more than for growth stocks and, as a result, compressing the value premium. This relationship holds when controlling for a comprehensive set of macroeconomic variables that are commonly found to be significant in the determination of the value premium. Our finding suggests that the uncertainty of earnings growth represents a fundamental risk factor distinct from broad economic state variables.

Our empirical finding suggests that the value premium may be considered an anomaly in empirical asset pricing because the traditional valuation models that produce this result do not account for the value enhancing effect of uncertainty in future earnings growth. Constant earnings growth can be accommodated in two different ways in a DCF valuation. Either, the numerator is adjusted for changes in future earnings, or, perhaps more readily, the denominator is modified. In other words, the interest rate used to discount future earnings is adjusted to account for constant earnings growth. Uncertainty in future earnings growth could theoretically be factored into the discount rate by adjusting the risk premium. However, the traditional DCF model offers no direct and explicit mapping mechanism between earnings growth volatility and potential adjustments to the discount rate.

Our results highlight the subtlety of the value-enhancing effect of volatility. Volatility is related to the value premium because its effect on firm value is dynamic in nature as a result of the highly non-linear value function. Our results suggest that the value premium is a product of the subtle interaction between drift and diffusion parameters in the earnings process. The value premium appears to be a result of the fact that the influence of volatility on firm value depends on the current value of the drift parameter that represents the deterministic component of earnings growth.

Traditional DCF models only account for the deterministic component of growth. Given differences in the relative importance of the deterministic and stochastic components of the earnings process in a value firm (drift $=0)$ and a growth firm (drift $>0$ ), the value firm is relatively more undervalued in the traditional DCF model than the growth firm. Our results suggest that in reality, investors do account for the effects of volatility, hence why we find empirical evidence for the inverse relationship between earnings growth volatility and the value premium. As a consequence, the alternative source we suggest for the value premium is supportive of the rational arguments in the debate seeking to determine the drivers of the value premium. 


\subsection{Hypothesis 2: EGVOL and the cross section of stock returns}

Table 6 shows the results of our firm-level Fama MacBeth regression analysis when considering a broad set of accounting and financial variables commonly found to be significantly associated with the cross section of stock returns.

Consistent with our hypothesis, earnings growth volatility has a significantly negative effect on stock returns. Higher earnings growth volatility adds value and thus decreases expected returns. Moreover, the results show the commonly reported failure of the CAPM to explain the cross-section of stock returns as the market factor is insignificant. Market value, our proxy for the size effect, and momentum, proxied by the past 6- and 36-month buy-and-hold returns on each stock, are also insignificant. On the other hand, the book-to-market effect, i.e. the value premium, remains significant in the presence of earnings growth volatility. This is not inconsistent with our theoretical proposition as we postulate that the value premium partly reflects information about earnings growth volatility. However, we do not rule out that the value premium contains price-sensitive information beyond earnings growth volatility.

Our result is consistent with recent findings in Penman and Reggiani (2011) and Penman, Reggiani, Richardson, and Tuna (2011) that earnings information is a firm characteristic that is significantly related to firm returns. Their proposed accountingbased explanation suggests that value firms are inherently riskier than growth firms since they carry a higher value of deferred, risky earnings on their balance sheet. Our results suggest that the actual value of the diffusion parameter in the earnings process, i.e. the actual amount of earnings risk, may in fact be identical in the value firm and in the growth firm.

However, the differential effects of risky earnings on firm value are dynamic and non-linear, driven by the drift component that can by definition not be identical between a growth firm and a value firm. Intuitively, the upside inherent in earnings growth volatility appears to be more valuable in an otherwise stabilised value firm than in a growth firm where a certain amount of earnings growth (and uncertainty) is a natural characteristic.

The inverse relationship we identify between earnings growth volatility and stock returns is also consistent with Donelson and Resutek (2011). They argue that their finding contrasts with previous studies documenting no relation between earnings risk and returns (Frankel and Litov, 2009; McInnis, 2010) because they use a more 
appropriate measure of earnings volatility. Our results suggest that apart from suitable metrics, an appropriate choice of valuation framework is an alternative means of establishing the effect of earnings growth volatility on stock returns.

Having established the direct relationship between earnings growth volatility and the value premium, as well as the influence of earnings growth volatility on stock returns, we also examine the role of earnings growth volatility in a Fama and French 25 portfolio pricing exercise (see Table 7 ). The first set of results reiterates the difficulties of the CAPM in explaining the cross-section of stock returns. The Fama and French three-factor model achieves a significant improvement in explanatory power. When we replace the value premium by the earnings growth volatility factor, the explanatory power remains broadly constant, confirming the close relationship between earnings growth volatility and the value premium from the perspective of their relative information content for asset pricing. The inclusion of the momentum factor improves the explanatory power of the model further while also considerably reducing the pricing error measured by the magnitude of the constant coefficient.

When we add the earnings growth volatility factor to this model, two insights are worth noting. First, the explanatory power continues to improve. Second, both the value premium and the earnings growth volatility factor significantly contribute to explaining the cross-section of stock returns. This result is consistent with our finding on the firm level and reiterates the relationship between earnings growth volatility and the value premium.

In order to explore the differential effect of earnings growth volatility on growth and value stocks further, we analyse a slope dummy that reflects the interaction between a portfolio consisting of value stocks and earnings growth volatility. The overall effect of earnings growth volatility on value firms is significantly negative, confirming our expectations that earnings growth volatility affects growth firms differently from value firms.

We interpret our finding as direct evidence that the value-enhancing effect of uncertainty in earnings growth appears to be relatively stronger in value stocks. Therefore, the resulting reduction in expected returns is more severe relative to growth stocks, producing the observed differential effect on characteristic portfolio returns. Our finding implies that investors rationally account for earnings growth volatility in firm valuation, although the traditional valuation framework has no scope to accommodate this factor explicitly. 
Our finding suggests therefore that it is merely a consequence of the incomplete description of firm value in the traditional valuation framework that gives rise to perceived valuation anomalies such as the value premium. Overall, our explanation of the value premium is broadly consistent with a rational risk-based perspective on this phenomenon.

For robustness, we also report the results of our asset pricing exercise when using the alternative test assets. Table 8 shows that our findings in relation to the significance of earnings growth volatility in explaining the cross-section of stock returns persist when considering these new test assets. The same is true for the inverse direction of the relationship we propose. Daniel and Titman (2011) argue that tests of factor models using the newly created test assets they propose have significantly higher power than test on portfolios that are sorted according to size and book to market only. The consistence of our findings suggest that the results we propose are robust to the application on these test assets that are arguably harder to price than the traditional Fama and French $(1992,1993)$ test assets.

\section{Conclusion}

In this study, we propose that the value premium may result from the uncertainty of future earnings growth. We show that the stochastic earnings valuation model may be an appropriate alternative valuation framework. Using this framework, we demonstrate that the value premium is a natural consequence of the fact that uncertainty enhances firm value relatively more for high book to market firms than for low book to market or growth firms. We examine the resulting testable hypotheses empirically. Our main results as well as a set of robustness tests lend support to our argument.

There appears to be a significant inverse relationship between the value premium and earnings growth volatility. This relationship is mirrored in a panel study of firm returns. A set of asset pricing tests also reveal a significant inverse relationship between the cross-section of stock returns and earnings growth volatility. In summary, earnings growth volatility enhances the value of high book to market firms more than for low book to market firms, thereby compressing relative expected returns and thus the value premium. 
The debate about the economic fundamentals driving the value premium is generally between rational explanations that involve the interpretation of the value premium as a compensation for risk, and irrational explanations, that view the value premium as a result of cognitive biases for instance. Within the context of this debate, our findings lend support to the rational explanation for the value premium. Once the effect of earnings growth volatility is suitably incorporated into firm valuation, the value premium emerges as a natural and rational consequence from the model.

On a broader scale, our findings suggest that higher-order moments of earnings and earnings growth are important variables in the determination of firm value. Ignoring these parameters may give rise to inappropriate valuations. In conclusion, our findings suggest that incomplete valuation models may have contributed to the confusion surrounding the determinants of the value premium. Higher-order moments governing a firm's earnings process are relevant in firm valuation, and these moments need to be accounted for in order to avoid perceived valuation anomalies such as the value premium. 


\section{References}

Alcock, J., T. Mollee, And J. Wood (2011): "Volatile earnings growth, the price of earnings and the value premium," Quantitative Finance, Forthcoming.

Aretz, K., S. M. Bartram, and P. F. Pope (2010): "Macroeconomic risks and characteristic-based factor models," Journal of Banking and Finance, 34, 13831399.

BANZ, R. W. (1981): "The relationship between return and market value of common stocks," Journal of Financial Economics, 9, 3-18.

BASU, S. (1983): "The relationship between earnings yield, market value, and return for NYSE common stocks: Further evidence," Journal of Financial Economics, $12,129-156$.

BHANDARI, L. C. (1988): "Debt/equity ratio and expected common stock returns: empirical evidence," Journal of Finance, 43(2), 507-528.

BlaCK, F. (1993): "The pricing of commodity contracts," Journal of Financial Economics, 3, 167-179.

Carhart, M. M. (1997): "On persistence in mutual fund performance," Journal of Finance, 52(1), 57-82.

Chui, A., And K. Wei (1998): "Book to market, firm size and the turn of the year effect: Evidence from Pacific Basin emerging markets," Pacific Basin Finance Journal, 6, 275-293.

Cochrane, J. H. (2005): Asset Pricing - Revised Edition. Princeton University Press.

Cooper, M. J., H. Gulen, And M. J. Schill (2008): "Asset growth and the cross-section of stock returns," Journal of Finance, 63(4), 1609-1651.

Daniel, K., And S. Titman (1997): "Evidence on the characteristics of cross sectional variation in stock returns," Journal of Finance, 52(1), 1-33.

_ (2011): "Testing factor-model explanations of market anomalies," Working Paper.

DeBondt, W. F. M., And R. H. Thaler (1985): "Does the stock market overreact?," Journal of Finance, 40, 793-805.

Dichev, I., AND V. TANG (2009): "Earnings volatility and earnings predictability," Journal of Accounting and Economics, 47(1-2), 160-181.

DicheV, I. D., AND V. W. TANG (2008): "Matching and the changing properties of accounting earnings over the last 40 years," The Accounting Review, 86, 945-974.

Donelson, D. C., And R. J. Resutek (2011): "The capital market consequences of earnings volatility: A new measure and new evidence," Working Paper.

FAmA, E., AND K. FRench (1992): "The cross-section of expected stock returns," Journal of Finance, 48, 427-465.

FAma, E., And K. French (1998): "Value versus growth: The international evidence," Journal of Finance, 53, 1975-1999.

FAma, E. F., AND K. R. French (1993): "Common risk factors in the returns on stocks and bonds," Journal of Financial Economics, 33, 3-56.

- (1995): "Size and book-to-market factors in earnings and returns," Journal of Finance, 50, 131-155.

- (1996): "Multifactor explanations of asset pricing anomalies," Journal of Finance, 51(1), 55-84.

FAma, E. F., And M. R. GibBons (1984): "A comparison of inflation forecasts," Journal of Monetary Economics, 13, 327-348.

Frankel, R., And L. Litov (2009): "Earnings persistence," Journal of Accounting 
and Economics, 47, 182-190.

Garcia-Feijoo, L., And R. Jorgensen (2010): "Can operating leverage be the cause of the value premium?," Financial Management, 39(3), 1127-1154.

Ghargori, P., H. Chan, And R. FAfF (2007): "Are the Fama-French factors proxying default risk?," Australian Journal of Management, 32, 223-249.

HAHN, J., AND H. LEE (2006): "Yield spreads as alternative risk factors for size and book-to-market," Journal of Financial and Quantitative Analysis, 41, 247-269.

Hall, J., AND M. Tochterman (2008): "Persistence in growth versus market expectations," Australian Journal of Management, 33(1), 169-199.

Hirshleifer, D., K. Hou, S. H. Teoh, And Y. Zhang (2004): "Do investors overvalue firms with bloated balance sheets?," Journal of Accounting and Economics, 38, 297-331.

Jegadeesh, N., And S. Titman (1993): "Returns to buying winners and selling losers: implications for stock market efficiency," Journal of Finance, 48, 65-91.

KeIm, D. B. (1983): "Size related anomalies and stock return seasonality: Further empirical evidence," Journal of Financial Economics, 12, 13-32.

KeLly, P. J. (2004): "Real and inflationary macroeconomic risk in the Fama and French size and book-to-market portfolios," Working paper, University of South California.

Kothari, S. P., J. Shanken, And R. Sloan (1995): "Another look at the crosssection of exptected returns," Journal of Finance, 50, 185-224.

Lakonishok, J., A. Shleifer, and R. Vishny (1994): "Contrarian investment, extrapolation and risk," Journal of Finance, 49, 1541-1578.

Lamont, O. (2001): "Economic tracking portfolios," Journal of Econometrics, 105, $161-184$.

LEWELlEN, J. (1999): "The time-series relations among expected return, risk, and book-to-market," Journal of Financial Economics, 54, 5-43.

Liew, J., And M. Vassalou (2000): "Can book-to-market, size, and momentum be risk factors that predict economic growth?," Journal of Financial Economics, $57,221-245$.

Lo, A., And C. MacKinlay (1990): "Data-snooping biases in tests of financial asset pricing models," Review of Financial Studies, 3, 431-467.

Loughran, T. (1997): "Book to market across firm size, exchange and seasonality: Is there an effect?," Journal of Financial and Quantitative Analysis, 32, 249-268.

McInnis, J. (2010): "Earnings smoothness, average returns, and implied cost of equity capital," The Accounting Review, 85, 315-341.

Merton, R. C. (1973): “An Intertemporal Capital Asset Pricing Model," Econometrica, 41(5), 867-887.

Murphy, K. M., and R. H. Topel (1985): "Estimation and inference in twostep econometric models," Journal of Business Economics and Statistics, 3(4), $370-379$.

NeWey, W. K., And K. D. West (1987): "A simple, positive semi-definite, heteroskedasticity and autocorrelation consistent covariance matrix," Econometrica, 55(3), 703-708.

Penman, S., And F. Reggiani (2011): "Returns to buying earnings and book value: Accounting for growth and risk," Review of Accounting Studies, Forthcoming.

Penman, S., F. Reggiani, S. A. Richardson, and I. Tuna (2011): "A characteristic model for asset pricing," Working Paper.

Petkova, R. (2006): "Do the Fama and French factors proxy for innovations in 
state variables?," Journal of Finance, 61, 581-612.

Pontiff, J., And A. Woodgate (2008): "Share issuance and cross-sectional returns," Journal of Finance, 63, 921-945.

Rosenberg, B., K. Reid, And R. Lanstein (1985): "Persuasive evidence of market inefficiency," Journal of Portfolio Management, 11, 9-17.

Shumway, T., AND V. Warther (1999): "The delisting bias in CRSP's NASDAQ data adnd its implications for the size effect," Journal of Finance, 54, 2361-2379.

SloAN, R. (1996): "Do stock prices fully reflect information in accruals and cash flows about future earnings?," Accounting Review, 289-71, 289-315.

Stattman, D. (1980): "Book values and stock returns," The Chicago MBA: A Journal of Selected Papers, 4, 25-45.

Titman, S., J. WeI, And F. XIE (2004): "Capital investments and stock returns," Journal of Financial and Quantitative Analysis, 39, 677-700.

VAssalou, M. (2003): "News related to future GDP growth as a risk factor in equity returns," Journal of Financial Economics, 68, 47-73.

Vassalou, M., AND Y. Xing (2004): "Default risk in equity returns," Journal of Finance, 59, 831-868. 


\section{Figures and Tables}

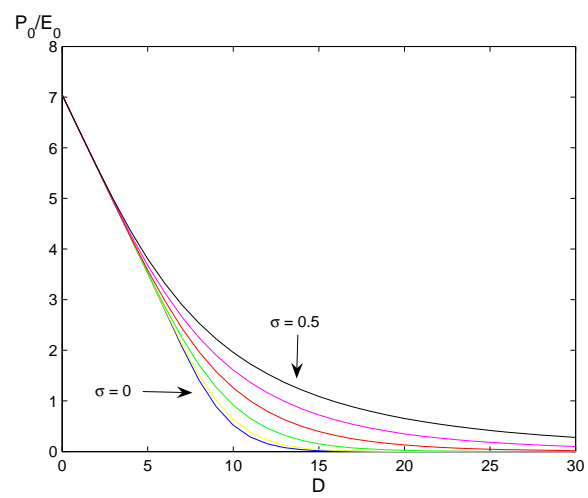

(a) PE Ratios for a 'Growth' firm: Expected Growth of Earnings, $g=0.2$.

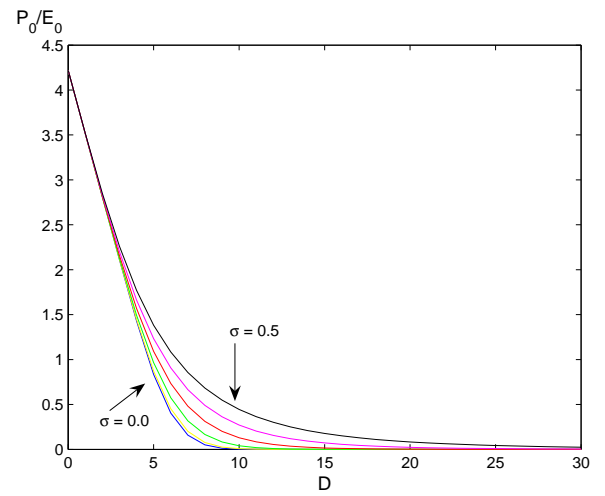

(b) PE Ratios for a 'value' firm: Expected Growth of Earnings, $g=0$.

Fig. 1. PE ratios as a function of debt and earnings volatility for 'growth' and 'value' firms with $r=0.07$, $T=5, E_{0}=1, A_{0}=0$.

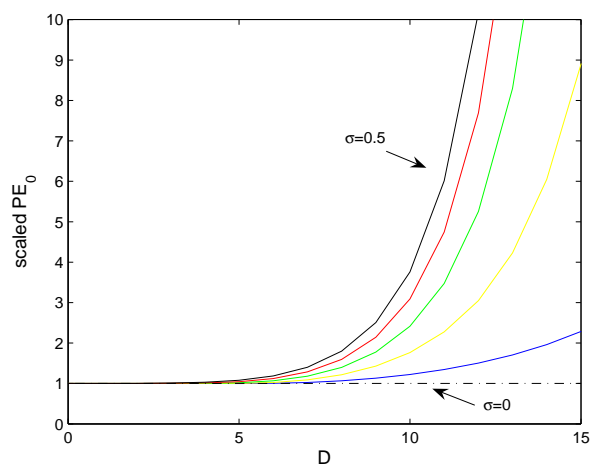

(a) Expected Growth of Earnings, $g=0.2$.

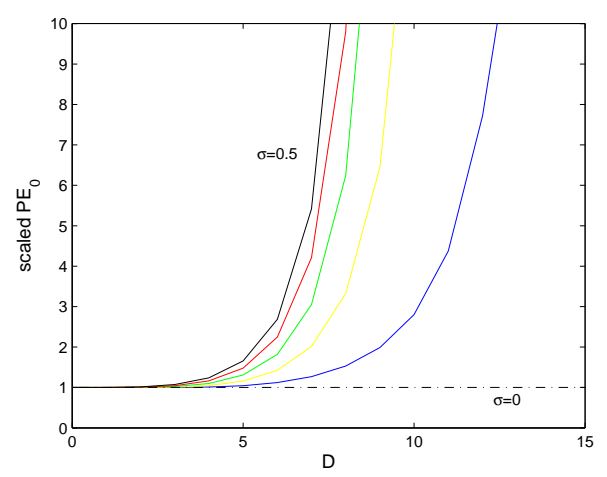

(b) Expected Growth of Earnings, $g=0$.

Fig. 2. Scaled $P / E$ as a function of debt and growth for the case $r=0.07, T=5, E_{0}=1, A_{0}=0$. Earnings volatility values include $\sigma=0,0.1, \ldots, 0.5$. The PE ratio's are scaled by the PE ratio for $\sigma=0$. 
Earnings growth volatility deciles: Financial and return characteristics

\begin{tabular}{|c|c|c|c|c|c|c|c|c|c|c|c|c|}
\hline Decile & 1 (Low) & 2 & 3 & 4 & 5 & 6 & 7 & 8 & 9 & 10 (High) & Spread (1-10) & t (spread) \\
\hline EGVOL & 0.03981 & 0.08316 & 0.12758 & 0.18106 & 0.24897 & 0.34187 & 0.48763 & 0.77848 & 1.46852 & 4.29631 & -4.257 & -14.21 \\
\hline ASSETG & 0.08978 & 0.09034 & 0.09234 & 0.09194 & 0.09455 & 0.09255 & 0.08959 & 0.07849 & 0.07584 & 0.05782 & 0.032 & 3.75 \\
\hline ASSETGL & 0.09253 & 0.09088 & 0.09239 & 0.09416 & 0.09467 & 0.09054 & 0.08444 & 0.08551 & 0.07633 & 0.06989 & 0.0226 & 2.69 \\
\hline ASSETS & 685.89 & 417.84 & 304.39 & 237.51 & 185.86 & 127.02 & 100.97 & 74.8 & 54.33 & 42.49 & 634.4 & 7.65 \\
\hline MV & 618.61 & 367.69 & 268.05 & 206.2 & 169.79 & 123.92 & 101.61 & 75.35 & 59.59 & 44.5 & 574.1 & 6.93 \\
\hline MV-AVG & 3329.94 & 2205.92 & 1573.46 & 1183.38 & 1089.77 & 801.11 & 656.5 & 380.3 & 327.24 & 210.59 & 3119.3 & 6.14 \\
\hline BM & 0.60502 & 0.65421 & 0.67494 & 0.68513 & 0.69018 & 0.71795 & 0.71719 & 0.72869 & 0.74635 & 0.75551 & -0.15 & -2.04 \\
\hline EP & 0.07312 & 0.07565 & 0.0748 & 0.07355 & 0.07149 & 0.06858 & 0.06332 & 0.04958 & 0.04241 & 0.02714 & 0.046 & 5.64 \\
\hline LEVERAGE & 0.27619 & 0.26118 & 0.23692 & 0.22369 & 0.21573 & 0.2025 & 0.19167 & 0.18033 & 0.16296 & 0.16791 & 0.108 & 7.15 \\
\hline ROA & 0.16225 & 0.15682 & 0.15412 & 0.14945 & 0.14567 & 0.13856 & 0.13085 & 0.10794 & 0.09474 & 0.06797 & 0.0943 & 16.34 \\
\hline BHRET6 & 0.06991 & 0.07226 & 0.07623 & 0.08311 & 0.07869 & 0.0799 & 0.08187 & 0.06635 & 0.04387 & 0.02802 & 0.0419 & 1.17 \\
\hline BHRET36 & 0.43984 & 0.42088 & 0.39899 & 0.3906 & 0.35985 & 0.32039 & 0.25826 & 0.15286 & 0.09133 & -0.03139 & 0.471 & 6.75 \\
\hline ACCRUALS & -0.03268 & -0.03162 & -0.02947 & -0.03057 & -0.02891 & -0.02857 & -0.02792 & -0.02655 & -0.02471 & -0.02317 & -0.0095 & -2.06 \\
\hline ISSUANCE & 0.26867 & 0.2246 & 0.22217 & 0.21377 & 0.22101 & 0.17545 & 0.19178 & 0.20731 & 0.16598 & 0.15292 & 0.116 & 3.58 \\
\hline
\end{tabular}

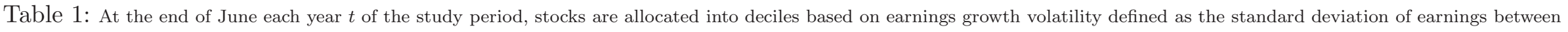

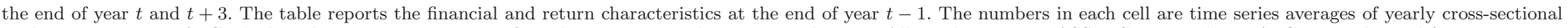
medians, except MV-AVG which is the time-series average of yearly cross-sectional mean capitalisation. All numbers except ASSETS, MV and MV-AVG are in decimal form. 
Average annual earnings growth volatility within decile portfolios in event time

\begin{tabular}{ccccccccccccc}
\hline YEAR & $\mathbf{1}$ (Low) & $\mathbf{2}$ & $\mathbf{3}$ & $\mathbf{4}$ & $\mathbf{5}$ & $\mathbf{6}$ & $\mathbf{7}$ & $\mathbf{8}$ & $\mathbf{9}$ & $\mathbf{1 0}$ (High) & $\mathbf{( 1 - 1 0 )}$ & $\mathbf{t}(\mathbf{s p r e a d})$ \\
\hline $\mathbf{- 5}$ & 0.1094 & 0.1361 & 0.1745 & 0.2103 & 0.2518 & 0.3149 & 0.3833 & 0.5362 & 0.6463 & 0.8245 & -0.7151 & -14.8 \\
$\mathbf{- 4}$ & 0.1032 & 0.1383 & 0.1731 & 0.2127 & 0.2475 & 0.3012 & 0.3975 & 0.5361 & 0.69 & 0.8931 & -0.7899 & -15.74 \\
$\mathbf{- 3}$ & 0.0987 & 0.1317 & 0.167 & 0.2079 & 0.2469 & 0.2989 & 0.3982 & 0.574 & 0.7738 & 0.9758 & -0.8771 & -18.86 \\
$\mathbf{- 2}$ & 0.0835 & 0.1171 & 0.1539 & 0.1949 & 0.2418 & 0.3022 & 0.4202 & 0.6617 & 1.0782 & 1.7705 & -1.6871 & -16.45 \\
$\mathbf{- 1}$ & 0.058 & 0.0959 & 0.1362 & 0.1861 & 0.2464 & 0.3269 & 0.4539 & 0.7339 & 1.3463 & 3.1767 & -3.1187 & -15.26 \\
$\mathbf{0}$ & 0.0398 & 0.0832 & 0.1276 & 0.1811 & 0.249 & 0.3419 & 0.4876 & 0.7785 & 1.4685 & 4.2963 & -4.2565 & -14.21 \\
$\mathbf{1}$ & 0.0579 & 0.0956 & 0.1348 & 0.1851 & 0.2453 & 0.3336 & 0.4684 & 0.766 & 1.3695 & 3.1516 & -3.0938 & -15.31 \\
$\mathbf{2}$ & 0.0834 & 0.1168 & 0.1511 & 0.1982 & 0.2436 & 0.3156 & 0.4318 & 0.7111 & 1.1235 & 1.8012 & -1.7178 & -16.62 \\
$\mathbf{3}$ & 0.0993 & 0.1303 & 0.1646 & 0.2027 & 0.2445 & 0.3123 & 0.4127 & 0.6479 & 0.8406 & 0.9047 & -0.8054 & -18.29 \\
$\mathbf{4}$ & 0.106 & 0.1351 & 0.1652 & 0.2051 & 0.244 & 0.2994 & 0.3981 & 0.5522 & 0.7292 & 0.8213 & -0.7153 & -18.13 \\
$\mathbf{5}$ & 0.1098 & 0.1362 & 0.164 & 0.206 & 0.2398 & 0.2977 & 0.3759 & 0.5205 & 0.6522 & 0.7811 & -0.6713 & -18.57 \\
\hline \hline
\end{tabular}

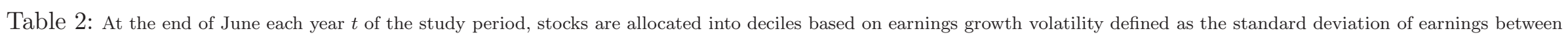

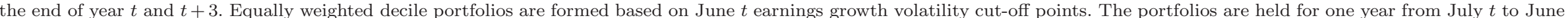

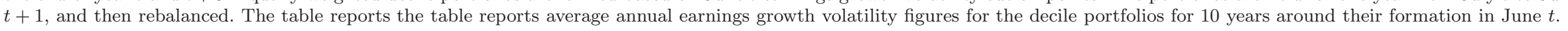


Average annual raw decile portfolio returns in event time

\begin{tabular}{ccccccccccccc}
\hline YEAR & $\mathbf{1}$ (Low) & $\mathbf{2}$ & $\mathbf{3}$ & $\mathbf{4}$ & $\mathbf{5}$ & $\mathbf{6}$ & $\mathbf{7}$ & $\mathbf{8}$ & $\mathbf{9}$ & $\mathbf{1 0}$ (High) & $\mathbf{( 1 - 1 0 )}$ & $\mathbf{t}(\mathbf{s p r e a d})$ \\
\hline $\mathbf{- 5}$ & 0.1163 & 0.111 & 0.0983 & 0.0766 & 0.0813 & 0.0653 & 0.0506 & 0.0396 & 0.02 & 0.0081 & 0.1081 & 2.34 \\
$\mathbf{- 4}$ & 0.1159 & 0.1138 & 0.1021 & 0.0866 & 0.0906 & 0.0778 & 0.0564 & 0.0453 & 0.0091 & 0.0052 & 0.1108 & 2.41 \\
$\mathbf{- 3}$ & 0.1222 & 0.1083 & 0.1021 & 0.0998 & 0.0879 & 0.076 & 0.0443 & 0.031 & 0.0217 & -0.0081 & 0.1302 & 3.02 \\
$\mathbf{- 2}$ & 0.1183 & 0.1125 & 0.1054 & 0.103 & 0.0914 & 0.0756 & 0.057 & 0.0247 & -0.0013 & -0.039 & 0.1573 & 3.72 \\
$\mathbf{- 1}$ & 0.117 & 0.1142 & 0.1133 & 0.1061 & 0.0915 & 0.0872 & 0.0664 & 0.0253 & -0.0214 & -0.0708 & 0.1878 & 4.39 \\
$\mathbf{0}$ & 0.1136 & 0.1033 & 0.0999 & 0.0861 & 0.0768 & 0.0719 & 0.0531 & 0.0265 & -0.0336 & -0.0724 & 0.1861 & 4.25 \\
$\mathbf{1}$ & 0.1123 & 0.1014 & 0.0897 & 0.079 & 0.0736 & 0.0631 & 0.0449 & 0.0156 & -0.0144 & -0.0487 & 0.161 & 3.59 \\
$\mathbf{2}$ & 0.1126 & 0.1039 & 0.0847 & 0.0726 & 0.0599 & 0.0334 & 0.0349 & 0.0076 & 0.0075 & 0.005 & 0.1076 & 2.32 \\
$\mathbf{3}$ & 0.0973 & 0.0879 & 0.0891 & 0.0753 & 0.0583 & 0.055 & 0.0442 & 0.0292 & 0.0332 & 0.0027 & 0.0945 & 1.98 \\
$\mathbf{4}$ & 0.0949 & 0.0946 & 0.0865 & 0.0793 & 0.0655 & 0.0642 & 0.0579 & 0.0406 & 0.0291 & 0.0039 & 0.0909 & 1.96 \\
$\mathbf{5}$ & 0.0917 & 0.0953 & 0.0832 & 0.0779 & 0.0755 & 0.0726 & 0.0542 & 0.0392 & 0.0384 & 0.0191 & 0.0725 & 1.6 \\
\hline \hline
\end{tabular}

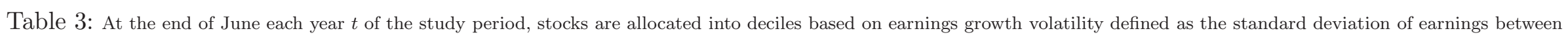

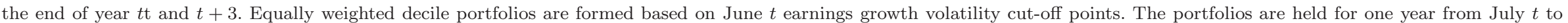
June $t+1$, and then rebalanced. The table reports the table reports average annual decile portfolio return figures for 10 years around their formation in June $t$. 
Summary statistics of the Fama and French $(1992,1993)$ factors and the EGVOL factor

\begin{tabular}{lcccccc}
\hline & MKT & SMB & HML & MOM & EGVOL & RF \\
\hline Mean & 0.4812 & 0.2247 & 0.4357 & 0.8579 & -0.0004 & 0.4596 \\
Standard deviation & 4.3607 & 3.1787 & 2.8615 & 3.9945 & 4.2027 & 0.2237 \\
Autocorrelation & 0.0544 & 0.0608 & 0.1380 & -0.0251 & 0.1995 & 0.9539 \\
Obs & 552 & 552 & 552 & 552 & 552 & 552 \\
\hline Correlation & MKT & SMB & HML & MOM & EGVOL & RF \\
\hline MKT & 1.0000 & & & & & \\
SMB & 0.3015 & 1.0000 & & & & \\
HML & -0.4003 & -0.2758 & 1.0000 & & & \\
MOM & -0.0774 & 0.0180 & -0.1227 & 1.0000 & & \\
EGVOL & 0.3983 & 0.7311 & -0.3592 & -0.0795 & 1.0000 & \\
RF & -0.0896 & -0.0651 & 0.0311 & -0.0036 & -0.1388 & 1.0000 \\
\hline \hline
\end{tabular}

Table 4

The table shows the summary statistics of the Fama French factors obtained from Kenneth French's website. The EGVOL factor is obtained from sorting sample stocks according to earnings growth volatility, calculating the average excess return of the resulting decile portfolios and taking the difference between the top and bottom $30 \%$ of decile portfolio excess returns.

Factor regressions of HML on EGVOL and macroeconomic variables

\begin{tabular}{lcccccc}
\hline Variable & Coefficient & Standard error & z-Statistic & $P>z$ & $95 \%$ Confidence interval \\
\hline EGVOL & $-0.416^{* * *}$ & 0.040 & -10.300 & 0.000 & -0.496 & -0.336 \\
UI & $103.975^{*}$ & 62.954 & 1.650 & 0.100 & -20.019 & 227.968 \\
DSV & $0.589^{* *}$ & 0.242 & 2.430 & 0.016 & 0.112 & 1.066 \\
ATS & 0.923 & 3.840 & 0.240 & 0.810 & -6.640 & 8.486 \\
STS & -0.009 & 0.092 & -0.100 & 0.923 & -0.190 & 0.172 \\
FX & $22.624^{* * *}$ & 8.457 & 2.680 & 0.008 & 5.967 & 39.281 \\
MYP & $-24.639^{*}$ & 17.179 & -1.430 & 0.153 & -58.473 & 9.196 \\
Constant & 0.753 & 0.376 & 2.000 & 0.047 & 0.012 & 1.494 \\
Observations & 256 & & & & & \\
$R^{2}$ & 0.3672 & & & & & \\
\hline \hline
\end{tabular}

Table 5

The table reports the results from an OLS time series regression of the value premium (HML factor) on earnings growth volatility (EGVOL) and the set of macroeconomic control variables. The standard errors, in parentheses, are corrected for the bias induced through the generated regressors MYP using the Murphy and Topel (1985) procedure. Significance is indicated as follows: *** $\mathrm{p}<0.01,{ }^{* *} \mathrm{p}<0.05,{ }^{*} \mathrm{p}<0.10$. 
Fama MacBeth regressions of firm-level returns on EGVOL and controls

\begin{tabular}{lcccccc}
\hline Variable & Coefficient & Standard error & t-Statistic & $P>|t|$ & $95 \%$ Confidence interval \\
\hline EGVOL & $-0.014^{* * *}$ & 0.003 & -4.050 & 0.000 & -0.021 & -0.007 \\
MKT & -0.034 & 0.028 & -1.190 & 0.242 & -0.091 & 0.024 \\
ACC & -0.025 & 0.095 & -0.260 & 0.794 & -0.216 & 0.166 \\
CI & -0.004 & 0.403 & -0.010 & 0.993 & -0.818 & 0.810 \\
NOA & -0.001 & 0.021 & -0.050 & 0.960 & -0.044 & 0.042 \\
EP & 0.133 & 0.082 & 1.620 & 0.113 & -0.033 & 0.298 \\
LEV & -0.010 & 0.022 & -0.450 & 0.654 & -0.054 & 0.034 \\
ISS & -46219.530 & 50435.730 & -0.920 & 0.365 & -148076.500 & 55637.490 \\
LAG & $-0.092^{* * *}$ & 0.031 & -2.940 & 0.005 & -0.155 & -0.029 \\
L2AG & -0.028 & 0.026 & -1.060 & 0.295 & -0.081 & 0.025 \\
BM & $0.005^{* * *}$ & 0.001 & 3.790 & 0.000 & 0.002 & 0.008 \\
MV & 0.000 & 0.000 & 0.100 & 0.923 & 0.000 & 0.000 \\
BH6 & -0.007 & 0.020 & -0.330 & 0.744 & -0.047 & 0.034 \\
BH36 & -0.006 & 0.006 & -1.040 & 0.304 & -0.019 & 0.006 \\
Constant & $0.116 * * *$ & 0.030 & 3.930 & 0.000 & 0.057 & 0.176 \\
Observations & 58,932 & & & & & \\
$R^{2}$ & 0.1123 & & & & \\
\hline \hline
\end{tabular}

Table 6

Annual stock returns over the study period are regressed on accounting and return-based controls. Coefficient estimates refer to time-series averages of cross-sectional regression coefficients obtained from the annual crosssectional regressions. The standard errors, in parentheses, are adjusted for autocorrelation. $R^{2}$ is an adjusted average value. Standard errors are adjusted for autocorrelation. All variables are winsorised at the 1st and 99th percentiles. Significance is indicated as follows: $* * * \mathrm{p}<0.01,{ }^{* *} \mathrm{p}<0.05,{ }^{*} \mathrm{p}<0.10$. 
Fama MacBeth regressions of the Fama and French $(1992,1993) 25$ portfolios on EGVOL and controls

\begin{tabular}{|c|c|c|c|c|c|c|}
\hline FF25 & I & II & III & IV & $\mathrm{V}$ & VI \\
\hline \multirow[t]{2}{*}{ MKT } & -0.549 & $-0.669 * *$ & $-1.433^{* * *}$ & -0.097 & -0.225 & -0.378 \\
\hline & $(0.433)$ & $(0.331)$ & $(0.419)$ & $(0.359)$ & $(0.365)$ & $(0.377)$ \\
\hline \multirow[t]{2}{*}{ SMB } & & 0.181 & 0.222 & 0.194 & $0.243^{*}$ & $0.262^{*}$ \\
\hline & & $(0.146)$ & $(0.142)$ & $(0.145)$ & $(0.142)$ & $(0.142)$ \\
\hline \multirow[t]{2}{*}{ HML } & & $0.459 * * *$ & & $0.489^{* * *}$ & $0.467^{* * *}$ & $0.591^{* * *}$ \\
\hline & & $(0.142)$ & & $(0.143)$ & $(0.142)$ & $(0.157)$ \\
\hline \multirow[t]{2}{*}{ EGVOL } & & & $-0.549 * *$ & & $-0.490^{* *}$ & $-0.936 * * *$ \\
\hline & & & $(0.253)$ & & $(0.247)$ & $(0.278)$ \\
\hline \multirow[t]{2}{*}{ MOM } & & & & $2.379^{* * *}$ & $2.378 * * *$ & $1.756^{* *}$ \\
\hline & & & & $(0.764)$ & $(0.764)$ & $(0.770)$ \\
\hline \multirow[t]{2}{*}{ VAL } & & & & & & $-0.159 *$ \\
\hline & & & & & & $(0.086)$ \\
\hline \multirow[t]{2}{*}{ VAL*EGVOL } & & & & & & $0.627^{* * *}$ \\
\hline & & & & & & $(0.185)$ \\
\hline \multirow[t]{2}{*}{ Constant } & $1.302^{* * *}$ & $1.175^{* * *}$ & $1.949 * * *$ & $0.644^{*}$ & $0.737^{* *}$ & $0.971^{* * *}$ \\
\hline & $(0.374)$ & $(0.300)$ & $(0.401)$ & $(0.341)$ & $(0.343)$ & $(0.369)$ \\
\hline$R^{2}$ & 0.24 & 0.47 & 0.47 & 0.47 & 0.53 & 0.55 \\
\hline No. obs. & 13,800 & 13,800 & 13,800 & 13,800 & 13,800 & 13,800 \\
\hline
\end{tabular}

Table 7

The table displays the coefficient estimates alongside their standard errors from a set of Fama MacBeth regressions of the Fama and French 25 portfolios sorted according to size (market value) and book to market ratio in different specifications over the study period. Coefficient estimates refer to time-series averages of cross-sectional regression coefficients obtained from the annual cross-sectional regressions. $R^{2}$ are adjusted average values. The standard errors, in parentheses, are adjusted for autocorrelation. Significance is indicated as follows: ${ }^{* * *} \mathrm{p}<0.01,{ }^{* *} \mathrm{p}<0.05,{ }^{*} \mathrm{p}<0.10$. 
Fama MacBeth regressions of Daniel and Titman (2011) 100 portfolios on EGVOL and controls

\begin{tabular}{lccccc}
\hline DT100 & I & II & III & IV & V \\
\hline MKT & -0.002 & -0.004 & $-0.005^{*}$ & -0.001 & -0.002 \\
& $(0.003)$ & $(0.003)$ & $(0.003)$ & $(0.003)$ & $(0.003)$ \\
SMB & & $0.006^{* * *}$ & $0.005^{* *}$ & $0.008^{* * *}$ & $0.006^{* * *}$ \\
& & $(0.002)$ & $(0.002)$ & $(0.002)$ & $(0.002)$ \\
HML & & $0.006^{* * *}$ & & $0.005^{* * *}$ & $0.005^{* * *}$ \\
& & $(0.002)$ & & $(0.002)$ & $(0.002)$ \\
EGVOL & & & $-3.331^{* * *}$ & & $-1.921^{* * *}$ \\
& & & $(0.701)$ & & $(0.610)$ \\
MOM & & & & $0.008^{* *}$ & 0.006 \\
& & & & $(0.004)$ & $(0.004)$ \\
Constant & $0.010^{* * *}$ & $0.006^{* * *}$ & $0.008^{* * *}$ & $0.004^{*}$ & $0.005^{* *}$ \\
& $(0.002)$ & $(0.002)$ & $(0.002)$ & $(0.002)$ & $(0.002)$ \\
$R^{2}$ & 0.16 & 0.24 & 0.23 & 0.24 & 0.24 \\
$\mathrm{~N}$ & 55,200 & 55,200 & 55,200 & 55,200 & 55,200 \\
\hline \hline
\end{tabular}

Table 8

The table displays the coefficient estimates alongside their standard errors from a set of Fama MacBeth regressions of the Daniel and Titman 100 portfolios sorted according to systematic risk (CAPM $\beta$ ) and book to market ratio in different specifications over the study period. Coefficient estimates refer to time-series averages of cross-sectional regression coefficients obtained from the annual cross-sectional regressions. $R^{2}$ are adjusted average values. The standard errors, in parentheses, are adjusted for autocorrelation. Significance is indicated as follows: ${ }^{* * *} \mathrm{p}<0.01,{ }^{* *} \mathrm{p}<0.05,{ }^{*} \mathrm{p}<0.10$. 


\section{Appendix}

\section{A Results for the estimation of future output growth}

\begin{tabular}{|c|c|c|c|c|}
\hline \multicolumn{5}{|l|}{ Panel (a) OLS } \\
\hline Variables & Coefficient & Standard error & t-Statistic & $P>|t|$ \\
\hline Market portfolio excess return & $0.0022^{* *}$ & 0.0010 & 2.14 & 0.033 \\
\hline Long-term government bond excess return t0- t-1 & 0.0400 & 0.1557 & 0.26 & 0.797 \\
\hline Medium-term government bond excess return t0- t-1 & -0.2670 & 0.2120 & -1.26 & 0.209 \\
\hline High-yield bond excess return t0- t-1 & $0.2696^{* * *}$ & 0.0944 & 2.86 & 0.005 \\
\hline Gold excess return t 0 - t- 1 & -0.0423 & 0.0656 & -0.65 & 0.519 \\
\hline Slope dummy market portfolio excess return (1987) & -0.0022 & 0.0018 & -1.25 & 0.212 \\
\hline Slope dummy market portfolio excess return (1996-2006) & -0.0001 & 0.0013 & -0.10 & 0.923 \\
\hline Constant & $0.0186^{* * *}$ & 0.0065 & 2.87 & 0.004 \\
\hline Observations & 256 & & & \\
\hline$R^{2}$ & 0.0417 & & & \\
\hline \multicolumn{5}{|l|}{ Panel (b) Newey-West, lag $l=11$} \\
\hline Variables & Coefficient & Standard error & t-Statistic & $P>|t|$ \\
\hline Market portfolio excess return & 0.0022 & 0.0014 & 1.6 & 0.112 \\
\hline Long-term government bond excess return t0- $t-1$ & 0.0400 & 0.1107 & 0.36 & 0.718 \\
\hline Medium-term government bond excess return t0- t-1 & -0.2670 & 0.2001 & -1.33 & 0.183 \\
\hline High-yield bond excess return t0- t- 1 & $0.2696^{* *}$ & 0.1167 & 2.31 & 0.022 \\
\hline Gold excess return t0 - t-1 & -0.0424 & 0.0694 & -0.61 & 0.542 \\
\hline Slope dummy market portfolio excess return (1987) & -0.0022 & 0.0010 & -1.61 & 0.108 \\
\hline Slope dummy market portfolio excess return (1996-2006) & -0.0001 & 0.0010 & -0.09 & 0.929 \\
\hline Constant & 0.0186 & 0.0187 & 1.00 & 0.320 \\
\hline Observations & 256 & & & \\
\hline$R^{2}$ & $\mathrm{n} / \mathrm{a}$ & & & \\
\hline
\end{tabular}

Table A.1

The table displays the coefficient estimates alongside their standard errors from an OLS regression (Panel (a)) of future industrial output growth on a set of base assets. $R^{2}$ are adjusted values where applicable. In Panel (b), the standard errors are corrected for autocorrelation using Newey West HAC standard errors with $l=11$. Significance is indicated as follows: *** $\mathrm{p}<0.01,{ }^{* *} \mathrm{p}<0.05,{ }^{*} \mathrm{p}<0.10$. 